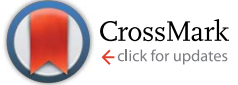

Cite this: RSC Adv., 2017, 7, 11719

Received 6th January 2017

Accepted 6th February 2017

DOI: $10.1039 / \mathrm{c} 7 \mathrm{ra00194k}$

rsc.li/rsc-advances

\section{Palladium-nickel catalysts based on ordered titanium dioxide nanorod arrays with high catalytic peformance for formic acid electro-oxidation $\dagger$}

\author{
Shangfeng Jiang, ${ }^{\text {ab }}$ Baolian $\mathrm{Yi}^{\mathrm{a}}{ }^{\mathrm{a}}$ Qing Zhao, ${ }^{\text {ab }}$ Hongmei $\mathrm{Yu}^{\star a}$ and Zhigang Shao*a \\ Ordered titanium dioxide nanorod arrays are prepared by a hydrothermal method and applied to the \\ catalyst supports of the palladium-nickel catalysts $\left(\mathrm{Pd}_{2} \mathrm{Ni}_{3}-\mathrm{TiO}_{2}\right)$ for formic acid oxidation. Due to the \\ three-dimensional catalytic structure and alloying effect, the $\mathrm{Pd}_{2} \mathrm{Ni}_{3}-\mathrm{TiO}_{2}$ exhibits superior mass activity \\ and long-term stability than those of $\mathrm{Pd}-\mathrm{TiO}_{2}$ and commercial $\mathrm{PdC}$ catalysts. The present work opens \\ a new approach to design catalysts with superior catalytic performance and durability for direct formic \\ acid fuel cells with three-dimensional catalytic structure.
}

\section{Introduction}

Direct formic acid fuel cells (DFAFCs) have potential to serve as promising power sources for portable electronics, due to their relatively high power density, low fuel crossover, and low pollutant emission. ${ }^{1,2}$ However, the development of DFAFCs is hindered by the sluggish formic acid electro-oxidation (FAO) and low durability of catalysts. ${ }^{3,4}$ It is known that the Pt-based catalysts are not suitable as the catalysts of FAO, because the catalysts are easily poisoned by CO during the FAO. Pd-based catalysts are believed to be more suitable for FAO due to their lower adsorption of $\mathrm{CO}$ intermediates in catalyzing formic acid. ${ }^{5-7}$ Nevertheless, the electrochemical activity and stability of Pd-based catalysts should be improved. Increasing the activity of Pd-based catalysts will lead to a low dosage of Pd in practical utilization.

Previous studies have proven that controlling the sizes and morphologies of Pd-based catalysts is an effective way to improve the catalytic performance for FAO. Several Pd-based catalysts have been demonstrated, such as Pd nanowires, ${ }^{8} \mathrm{Pd}$ nanorods, ${ }^{9}$ and the combination of Pd with transition metals (e.g. , $\mathrm{Ni}, \mathrm{Co}, \mathrm{Fe}, \mathrm{Cu}$ ), $\mathrm{Ag}$ or $\mathrm{P}$ to form bimetallic compounds. ${ }^{\mathbf{1 0 - 1 6}}$ Nevertheless, the catalytic structure and the support material also have an impact on the catalytic activity of the electrocatalysts. ${ }^{17}$ Metal oxides can be used as the support materials in fuel cells, due to their high corrosion resistance, reasonable surface area, and mechanical strength. ${ }^{18,19}$ Among them, Tibased oxides has been applied as the catalyst support material

${ }^{a}$ Fuel Cell System and Engineering Laboratory, Dalian Institute of Chemical Physics, Chinese Academy of Sciences, 457 Zhongshan Road, Dalian 116023, PR China. E-mail:hmyu@dicp.ac.cn; zhgshao@dicp.ac.cn

${ }^{b}$ University of Chinese Academy of Sciences, Beijing 100039, PR China

$\dagger$ Electronic supplementary information (ESI) available. See DOI: 10.1039/c7ra00194k of fuel cells. Subramanian et al. applied anodized $\mathrm{TiO}_{2}$ nanotubes ( $\mathrm{T} \_\mathrm{NT}$ ) as the Pt support for simultaneous FAO and photoassisted FAO, which generates around 39-fold higher current density than that of the pure T_NT. ${ }^{20}$ Xing et al. investigated the fine-tuned pore structured $\mathrm{TiO}_{2}-\mathrm{C}$ as the $\mathrm{Pt}$ or $\mathrm{Pd}$ catalyst supports for the electro-oxidation of methanol or formic acid, which showed a much superior catalytic performance than that of the carbon support. ${ }^{21}$

Based on the above considerations, we present $\mathrm{TiO}_{2}$ NRs as the catalyst supports of Pd-based catalysts. To the best of our knowledge, the Pd-based alloy nanoparticles supported on the $\mathrm{TiO}_{2}$ NRs are rarely reported as the catalysts toward FAO. The advantages of this approach are listed: (1) high transport rate of $\mathrm{HCOOH}$; (2) high electrochemical surface area (ECSA) and high utilization of electrocatalysts; (3) direct charge carrier transport pathways. More importantly, we combine high catalytic activity and advanced catalytic structure to show the highest electrochemical activity. Compared with the commercial PdC catalyst and pure $\mathrm{Pd}-\mathrm{TiO}_{2}$ catalysts, the $\mathrm{Pd}_{2} \mathrm{Ni}_{3}-\mathrm{TiO}_{2}$ catalyst exhibited higher electrochemical activity and stability.

\section{Experimental}

\section{Preparation of $\mathrm{TiO}_{2} \mathrm{NRs}$}

Oriented $\mathrm{TiO}_{2}$ NRs were hydrothermally grown on carbon fibers by a seed-assisted method and the details of the preparation process are shown in the previous report. ${ }^{22,23}$ There are two key points for the formation of the oriented $\mathrm{TiO}_{2}$ NRs, which are exactly controlling the concentration of the titanium(Iv) chloride aqueous solution and tetrabutyl titanate (TBT) solution.

\section{Preparation of the $\mathrm{PdNi}-\mathrm{TiO}_{2}$ and $\mathrm{Pd}-\mathrm{TiO}_{2}$}

For the preparation of the $\mathrm{PdNi}-\mathrm{TiO}_{2}$ electrode, $\mathrm{Ni}$ and $\mathrm{Pd}$ catalysts were sputtered onto the $\mathrm{TiO}_{2}$ NRs by physical vapor 
deposition (PVD) in a row and the whole sputtering time was maintained for $15 \mathrm{~min}$ and $6 \mathrm{~min}$, respectively. After that, to increase the crystal size of the catalysts, the as-prepared samples were heat-treated at $300{ }^{\circ} \mathrm{C}$ under $5 \% \mathrm{H}_{2} / \mathrm{Ar}$ gas for $2 \mathrm{~h}$. For the preparation of $\mathrm{Pd}-\mathrm{TiO}_{2} \mathrm{NRs}$, the preparation process was similar to that of $\mathrm{PdNi}-\mathrm{TiO}_{2}$ NRs without $\mathrm{Ni}$ deposition.

\section{Physical characterization}

Field-emission scanning electron microscopy (FESEM, Zeiss supra 55) and transmission electron microscopy (TEM, JEM2000EX) are employed to observe the morphology of the asprepared samples. High-resolution transmission electron microscopy (HRTEM, JEM-2100F) characterization and energydispersive X-ray (EDX) analysis were conducted using FEITecani G2F30 microscopy operating at $300 \mathrm{kV}$. The crystal phases of the samples were monitored by X-ray diffraction (XRD, BrukerD8, Cu K $\alpha$ radiation). X-ray photoelectron spectroscopy (XPS, Thermo Scientific ESCALab $250 \mathrm{Xi}$ spectrometer, Al K $\alpha$ in twin anode) was used to measure the chemical state of all the samples. Inductively coupled plasma-optical emission spectroscopy (ICP-OES, PerkinElmer 7300DV, USA) was applied to determine the metal loadings in the samples.

\section{Electrochemical characterization}

The electrochemical properties of all the samples were measured using a conventional three-electrode cell at room temperature. The $\mathrm{PdNi}-\mathrm{TiO}_{2} \quad \mathrm{NRs}, \quad \mathrm{Pd}-\mathrm{TiO}_{2} \quad \mathrm{NRs}$, and a commercial PdC (BASF, 20\% PdC) based electrode were used as the working electrodes. A saturated calomel electrode (SCE) and a Pt-foil served as the reference electrode and the counter electrode, respectively. The $\mathrm{PdNi}-\mathrm{TiO}_{2} \mathrm{NRs}$ and $\mathrm{Pd}-\mathrm{TiO}_{2} \mathrm{NRs}$ are directly used as the working electrode without additional Nafion ionomer. The commercial PdC based electrode was prepared by spraying the commercial PdC and Nafion ionomer $(\mathrm{I} / \mathrm{C}=0.5)$ on a commercial gas diffusion layer (GDL). Prior to all the experiments, the mixture was saturated with $\mathrm{N}_{2}$ gas. Cyclic voltammetry (CV) and chronoamperometric (CA) experiments were carried out in a mixture including $0.5 \mathrm{M} \mathrm{H}_{2} \mathrm{SO}_{4}+$ $0.5 \mathrm{M} \mathrm{HCOOH}$. CV curves were tested at the potential window between $0-1.0 \mathrm{~V}$ ( $v s$. SCE) with the sweeping rate of $50 \mathrm{mV} \mathrm{s}^{-1}$. CA curves were recorded at $0.55 \mathrm{~V}$ ( $v s$. SCE) and maintained for $4000 \mathrm{~s}$.

\section{Results and discussion}

$\mathrm{TiO}_{2}$ NRs were directly grown on carbon paper by a hydrothermal method. ${ }^{22-24} \mathrm{PdNi}^{-\mathrm{TiO}_{2}} \mathrm{NRs}$ and $\mathrm{Pd}-\mathrm{TiO}_{2} \mathrm{NRs}$ were deposited onto the $\mathrm{TiO}_{2} \mathrm{NRs}$ by PVD and heat-treated in $5 \% \mathrm{H}_{2}$ / Ar gas. Here the carbon paper is employed as a current collector, and the as-prepared electrodes can potentially be used as an anodic electrode of DFAFCs directly.

The XRD analysis was first applied to monitor the corresponding crystal phase of all the samples and is displayed in Fig. 1. The as-prepared products are mainly composed of rutile $\mathrm{TiO}_{2}$ phases according to JCPDS 21-1276. The Ti 2p XPS

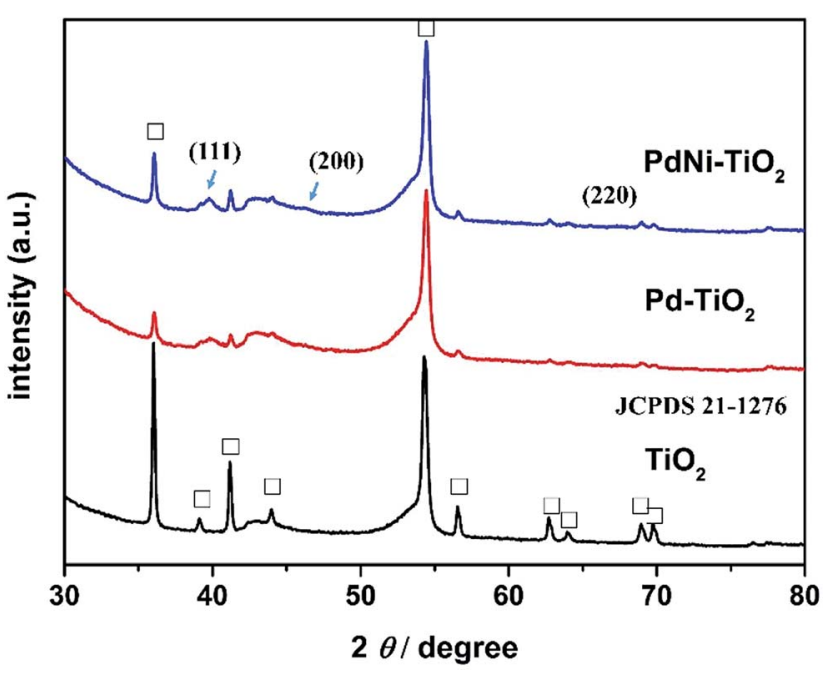

Fig. 1 XRD patterns of $\mathrm{TiO}_{2}, \mathrm{Pd}-\mathrm{TiO}_{2}$, and $\mathrm{PdNi}-\mathrm{TiO}_{2}$.

spectrum of the as-prepared sample is shown in Fig. S2. $\dagger$ The binding energies of $\mathrm{Ti} 2 \mathrm{p}_{1 / 2}$ and $\mathrm{Ti} 2 \mathrm{p}_{3 / 2}$ are $458.58 \mathrm{eV}$ and $464.38 \mathrm{eV}$, respectively. Since the binding energy of $\mathrm{Ti}^{4+}$ is $458.5 \mathrm{eV}$, the XPS data prove the presence of $\mathrm{TiO}_{2}$. After deposition of the Pd and PdNi nanoparticles, the (111) peak for the $\mathrm{Pd}-\mathrm{TiO}_{2}$ and $\mathrm{PdNi}-\mathrm{TiO}_{2}$ is obviously in the XRD pattern (Fig. 1). Due to the low metal content in the products, the diffraction peaks of the (200), and (220) planes of the Pd-based catalysts are not specified in the XRD patterns.

FESEM images of $\mathrm{Pd}-\mathrm{TiO}_{2}$ NRs and $\mathrm{PdNi}-\mathrm{TiO}_{2}$ NRs grown on carbon paper are shown in Fig. $2 \mathrm{a}$ and $\mathrm{b}$ (inset). The oriented $\mathrm{TiO}_{2}$ nanorods grew on the surface of carbon fibres, and the mean diameters of the $\mathrm{TiO}_{2}$ nanorods are about $120 \mathrm{~nm}$ (Fig. S1 $\dagger$ ). After deposition of the Pd-based catalysts onto the $\mathrm{TiO}_{2}$ NRs, the resulting samples are heat-treated in $5 \% \mathrm{H}_{2} / \mathrm{Ar}$ gas at $300{ }^{\circ} \mathrm{C}$ for $2 \mathrm{~h}$. The morphology and structure of the asprepared samples are not obviously changed compared with that of $\mathrm{TiO}_{2}$ NRs. The TEM image of a $\mathrm{TiO}_{2}$ nanorod shows that the surface of the $\mathrm{TiO}_{2}$ nanorod is smooth (Fig. 2c). The Pd nanoparticles and PdNi nanoparticles are dispersed on the $\mathrm{TiO}_{2}$ nanorod (Fig. 2d and e) and the size distributions of the Pd and PdNi nanoparticles are shown in Fig. $2 d$ and e (inset) and S3. $\dagger$ Fig. $2 \mathrm{~d}$ and e show that the mean sizes of the Pd and PdNi catalysts are about $3.52 \mathrm{~nm}$ and $4.24 \mathrm{~nm}$, respectively. However, the sizes of some other PdNi particles are about $20 \mathrm{~nm}$ (Fig. S3†), which are larger than Pd nanoparticles. The average sizes of the Pd and PdNi catalysts according to XRD are $6.09 \mathrm{~nm}$ and $7.53 \mathrm{~nm}$, respectively, which are larger than the particle sizes of the Pd-based catalysts. Since the general detection depth of XRD measurements is around $10 \mathrm{~nm}$, the composition detected by XRD indicates both surface and bulk atoms of the Pd-based catalysts.

The HR-TEM image reveals that the PdNi particles are crystalline and the lattice structure is clear (Fig. 2f). The (111) lattice spacing of the PdNi nanoparticles was measured to be $0.219 \mathrm{~nm}$, which is between that of Pd $(0.223 \mathrm{~nm})$ and $\mathrm{Ni}(0.20$ $\mathrm{nm}$ ), confirming the formation of PdNi alloy in the as-prepared 

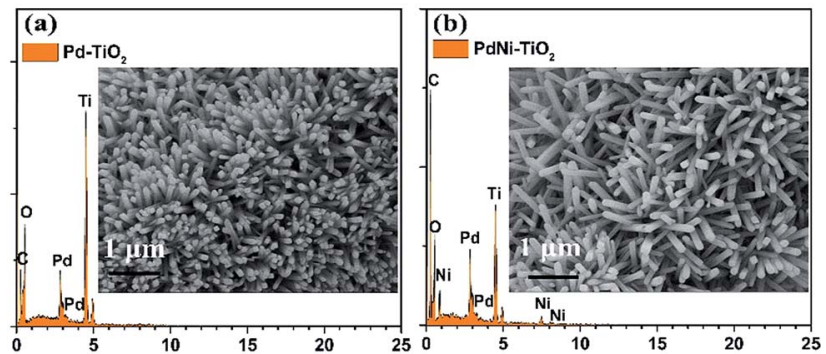

(c)

(d)
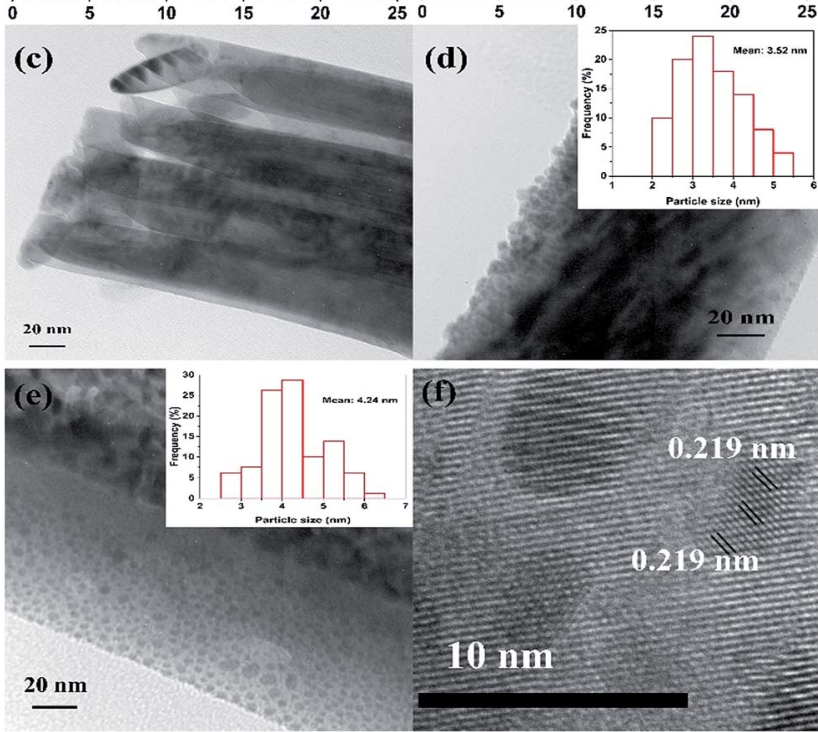

(1)

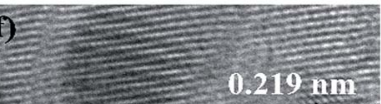

$0.219 \mathrm{mim}$

$10 \mathrm{~mm}$

Fig. 2 FESEM images and EDX spectra of $\mathrm{Pd}-\mathrm{TiO}_{2} \mathrm{NRs}(\mathrm{a})$ and $\mathrm{PdNi}-$ $\mathrm{TiO}_{2} \mathrm{NRs}(\mathrm{b})$; TEM images of $\mathrm{TiO}_{2}$ (c), $\mathrm{Pd}-\mathrm{TiO}_{2}$ (d) and $\mathrm{PdNi}-\mathrm{TiO}_{2}$ (e); and HRTEM image of $\mathrm{PdNi}-\mathrm{TiO}_{2}$. The inset pictures in (d) and (e) are the size distributions of $\mathrm{Pd}$ and $\mathrm{PdNi}$ catalysts, respectively.

samples. ${ }^{25}$ EDX analysis was also carried out to measure the composition of the $\mathrm{PdNi}-\mathrm{TiO}_{2}$ catalysts. The spectrum confirms that Pd and $\mathrm{Ni}$ elements exist in the PdNi nanoparticles and their atomic ratio is $1: 1.72$ (Fig. $\mathrm{S} 4 \dagger$ ). In addition, the Pd and $\mathrm{Ni}$ content in the as-prepared samples is estimated by ICP-OES,

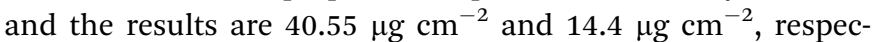
tively. Thus, the atomic ratio of $\mathrm{Pd}$ and $\mathrm{Ni}$ in the $\mathrm{PdNi}-\mathrm{TiO}_{2}$ catalysts is $1: 1.55$ according to the result of ICP-OES, which is consistent with the EDX data. Thus, the $\mathrm{PdNi}-\mathrm{TiO}_{2}$ catalysts can be named as $\mathrm{Pd}_{2} \mathrm{Ni}_{3}-\mathrm{TiO}_{2}$ according to the data of ICP-OES. Meanwhile, the Pd loading of the $\mathrm{Pd}-\mathrm{TiO}_{2} \mathrm{NRs}$ is measured as $29.7 \mu \mathrm{g} \mathrm{cm}^{-2}$.

XPS was applied to analyze the chemical states and electronic states of Pd and Ni in the as-prepared samples. The Pd 3d spectra for the $\mathrm{PdNi}-\mathrm{TiO}_{2} \mathrm{NRs}$ and $\mathrm{Pd}-\mathrm{TiO}_{2}$ NRs are shown in Fig. 3a. The Pd 3d XPS spectra of $\mathrm{Pd}-\mathrm{TiO}_{2}$ NRs show the binding energies of $\mathrm{Pd}^{0} 3 \mathrm{~d}\left(3 \mathrm{~d}_{5 / 2}=335.26 \mathrm{eV} ; 3 \mathrm{~d}_{3 / 2}=340.53 \mathrm{eV}\right.$, Fig. $\left.3 \mathrm{a}\right)$, which are slightly higher than those of bulk $\operatorname{Pd~}\left(3 \mathrm{~d}_{5 / 2}=\right.$ $\left.334.90 \mathrm{eV} ; 3 \mathrm{~d}_{3 / 2}=340.15 \mathrm{eV}\right){ }^{26}$ The slight shift of binding energies of $\mathrm{Pd}^{0}$ to higher ones may be attributed to the significant interaction between $\mathrm{Pd}$ nanoparticles and $\mathrm{TiO}_{2}$ supports. Meanwhile, after the formation of PdNi alloys, the Pd $3 d$ binding energy of $\mathrm{Pd}_{2} \mathrm{Ni}_{3}-\mathrm{TiO}_{2} \mathrm{NRs}$ is shifted to a more negative position than that of $\mathrm{Pd}-\mathrm{TiO}_{2} \mathrm{NRs}$. This shift may be attributed to the difference of the electronegativity between $\mathrm{Pd}$ and $\mathrm{Ni}$,
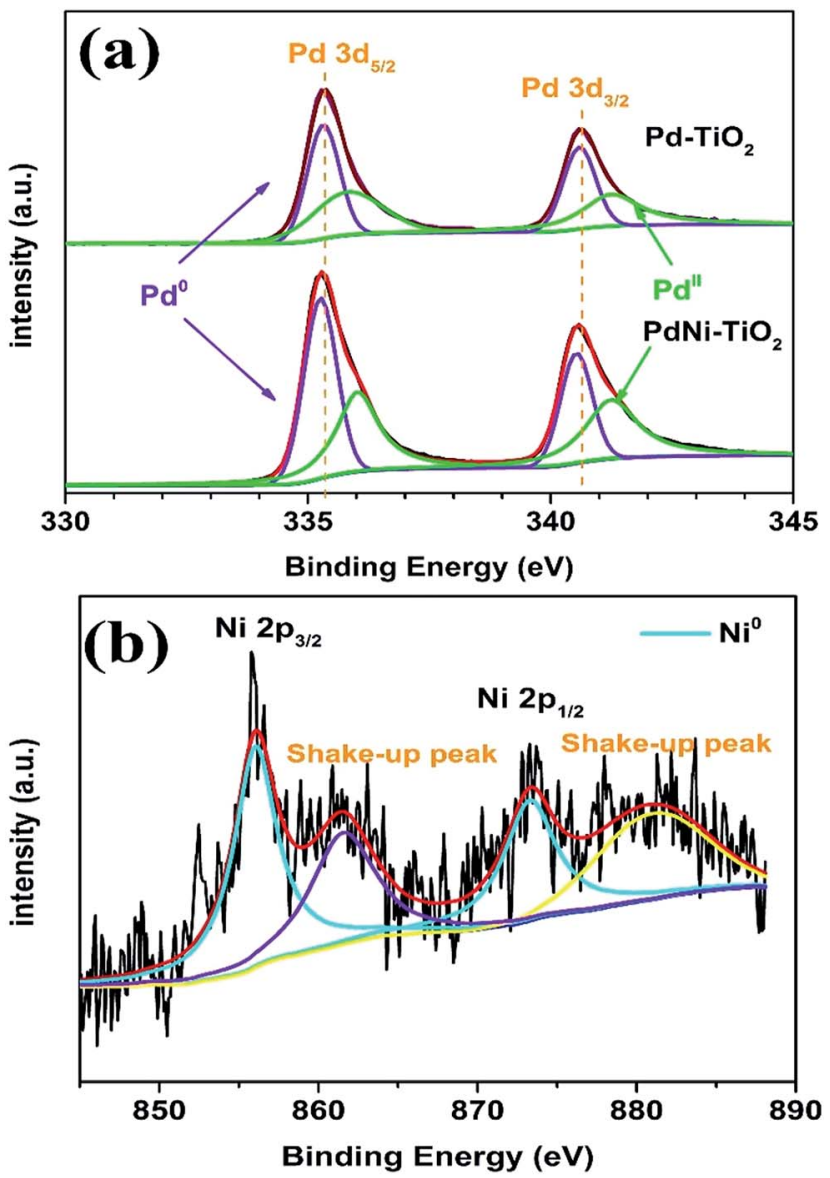

Fig. 3 XPS spectra of (a) Pd 3d carried out on the $\mathrm{Pd}-\mathrm{TiO}_{2} \mathrm{NRs}$ and $\mathrm{PdNi}-\mathrm{TiO}_{2} \mathrm{NRs}$ and (b) $\mathrm{Ni} 2 \mathrm{p}$ carried out on the $\mathrm{PdNi}-\mathrm{TiO}_{2} \mathrm{NRs}$.

resulting in a partial electron transfer from $\mathrm{Ni}$ to $\mathrm{Pd}$, which would change the penetration of outer electron density of $\mathrm{Pd} .^{27}$ Fig. $3 \mathrm{~b}$ shows that $\mathrm{Ni}(\mathrm{OH})_{2}$ and $\mathrm{NiOOH}$ with obvious shake-up peaks can be seen at higher binding energies than those of the high-energy band ( $\left.\mathrm{Ni} 2 \mathrm{p}_{3 / 2}\right)$ and the low-energy band (Ni $2 \mathrm{p}_{1 /}$ 2). ${ }^{25}$

To investigate the electronic activity of the as-prepared $\mathrm{Pd}_{2} \mathrm{Ni}_{3}-\mathrm{TiO}_{2} \mathrm{NRs}$, we employed FAO as the model system, comparing with pure $\mathrm{Pd}-\mathrm{TiO}_{2}$ NRs and commercial PdC. Typical Pd electrochemical behaviours of all the Pd-based electrocatalysts and the $\mathrm{TiO}_{2}$ sample were observed in $0.5 \mathrm{M}$ $\mathrm{H}_{2} \mathrm{SO}_{4}$ (Fig. 4a and $\mathrm{S}^{\dagger} \dagger$ ). The ECSA was estimated according to the area of hydrogen adsorption peaks and the calculation equation is according to that previously reported. ${ }^{17,28,29}$ The CVs of $\mathrm{Pd}-\mathrm{TiO}_{2}$, and $\mathrm{Pd}_{2} \mathrm{Ni}_{3}-\mathrm{TiO}_{2}$ are shown in Fig. 4a. The calculated ECSAs of $\mathrm{Pd}-\mathrm{TiO}_{2}, \mathrm{Pd}_{2} \mathrm{Ni}_{3}-\mathrm{TiO}_{2}$, and commercial PdC are $53.6 \mathrm{~m}^{2} \mathrm{~g}^{-1}, 43.6 \mathrm{~m}^{2} \mathrm{~g}^{-1}$, and $37.6 \mathrm{~m}^{2} \mathrm{~g}^{-1}$, respectively. Since some PdNi nanoparticles are larger than the Pd nanoparticles at the surface of the $\mathrm{TiO}_{2}$ nanorods, the ECSA of the $\mathrm{Pd}_{2} \mathrm{Ni}_{3}-\mathrm{TiO}_{2}$ NRs is smaller than that of the $\mathrm{Pd}-\mathrm{TiO}_{2}$.

The electrocatalytic properties of the $\mathrm{Pd}_{2} \mathrm{Ni}_{3}-\mathrm{TiO}_{2}$ catalysts towards FAO were investigated in a $0.5 \mathrm{M} \mathrm{H}_{2} \mathrm{SO}_{4}+0.5 \mathrm{M}$ $\mathrm{HCOOH}$ mixture. The electrocatalytic properties of the $\mathrm{Pd}-\mathrm{TiO}_{2}$ and the commercial PdC toward FAO were measured for 

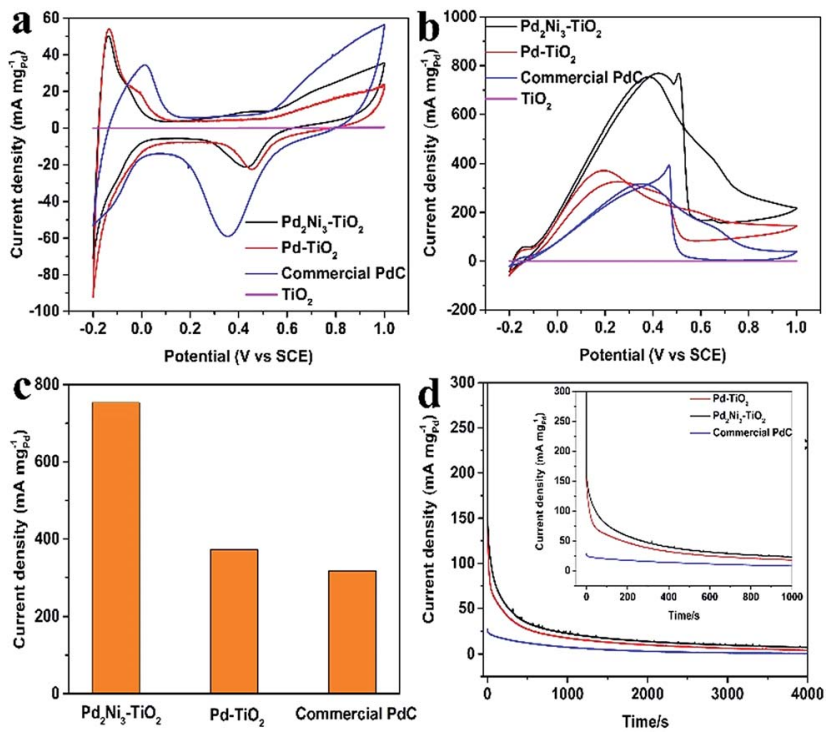

Fig. 4 (a) $\mathrm{CVs}$ of $\mathrm{Pd}-\mathrm{TiO}_{2}, \mathrm{Pd}_{2} \mathrm{Ni}_{3}-\mathrm{TiO}_{2}$, and commercial $\mathrm{PdC}$ in the $0.5 \mathrm{M} \mathrm{H}_{2} \mathrm{SO}_{4}$ solution at a sweeping rate of $50 \mathrm{mV} \mathrm{s}^{-1}$; (b) $\mathrm{CVs}$ of $\mathrm{FAO}$ of all samples in $0.5 \mathrm{M} \mathrm{H}_{2} \mathrm{SO}_{4}$ solution $+0.5 \mathrm{M} \mathrm{HCOOH}$ at the scan rate of $50 \mathrm{mV} \mathrm{s}^{-1}$; (c) the mass activity of different catalysts at the peak position; (d) $\mathrm{CA}$ curves of all samples in $0.5 \mathrm{M} \mathrm{H}_{2} \mathrm{SO}_{4}$ solution + $0.5 \mathrm{M}$ $\mathrm{HCOOH}$ at $0.25 \mathrm{~V}$. The unit of current density of the $\mathrm{TiO}_{2}$ sample is $\mathrm{mA}$ $\mathrm{cm}^{-2}$.

comparison. Fig. 4b shows the CV curves of FAO of different catalysts. All the current densities of FAO of different samples were normalized by $\mathrm{Pd}$ loading (mass activity). The $\mathrm{TiO}_{2}$ samples show no catalytic performance in the $0.5 \mathrm{M} \mathrm{H}_{2} \mathrm{SO}_{4}$ and $0.5 \mathrm{M} \mathrm{H}_{2} \mathrm{SO}_{4}$ containing 0.5 M HCOOH mixture (Fig. 4a, b, S5a and $\mathrm{S} 4 \mathrm{~b} \dagger)$. Meanwhile, after deposition of Pd nanoparticles, the as-prepared $\mathrm{Pd}-\mathrm{TiO}_{2}$ catalyst exhibits high catalytic activity as its mass density is $371.87 \mathrm{~mA} \mathrm{mg}^{-1}$, which is around 1.17 -fold higher than that of commercial PdC (Fig. 4c). The enhancement of the onset potential of the as-prepared $\mathrm{Pd}-\mathrm{TiO}_{2}$ catalysts compared with the commercial PdC for FAO might be explained by the formation of a three-dimensional catalytic structure. The performance will be further improved by adding Ni element to Pd. Many studies shows that the highest FAO performance of a PdNi catalyst is when the atomic ratio of $\mathrm{Pd}$ and $\mathrm{Ni}$ is around $1: 1 .^{10,25,30}$ After alloying with $\mathrm{Ni}$, the catalytic activity of $\mathrm{Pd}_{2} \mathrm{Ni}_{3}-$ $\mathrm{TiO}_{2}$ is further improved (753.42 mA mg ${ }_{\mathrm{Pd}}{ }^{-1}$, Fig. 4b), indicating the electronic structure modification after Pd alloying with $\mathrm{Ni}$, as demonstrated in the XPS analysis, which has been observed in many other Pd-based alloys. ${ }^{31}$ The FAO reaction occurs over the surface atom layer of the Pd-based catalysts for the test samples. With a similar amount of $\mathrm{Pd}-\mathrm{TiO}_{2}, \mathrm{Pd}_{2} \mathrm{Ni}_{3}-$ $\mathrm{TiO}_{2}$ shows better catalytic activity toward the FAO than Pd$\mathrm{TiO}_{2}$. Ni element does not catalyze the FAO reaction, thus the $\mathrm{Ni}$ must be improving the catalytic activity of the $\mathrm{Pd}$ element toward FAO in such a way that the FAO rate is increased consequently. ${ }^{32}$ One possible effect is that the Pd surface electronic structure is perturbed by $\mathrm{Ni}^{33}$ The d-band center of the catalysts will be altered and the electronic structure of the Pd surface layer will be affected by the formation of the PdNi alloy. ${ }^{34}$ During the FAO reaction, the HCOOad (HCOO-Pd) is formed firstly through breaking the $\mathrm{O}-\mathrm{H}$ bond of $\mathrm{HCOOH} .{ }^{35}$ The possible reaction steps are listed as follows. ${ }^{35,36}$

$$
\begin{gathered}
\mathrm{HCOOH}+\mathrm{Pd} \rightarrow \mathrm{HCOO}-\mathrm{Pd}+\mathrm{H}^{+}+\mathrm{e}^{-} \\
\mathrm{HCOO}-\mathrm{Pd} \rightarrow \mathrm{Pd}-\mathrm{H}+\mathrm{CO}_{2} \\
\mathrm{Pd}-\mathrm{H} \rightarrow \mathrm{Pd}+\mathrm{H}^{+}+\mathrm{e}^{-}
\end{gathered}
$$

After the Pd d-band center is shifted to an optimum value, the Pd-adsorbate bond strength will be optimized. ${ }^{32}$ We believe that the Pd d-band center is shifted to an optimum value after alloying with $\mathrm{Ni}$, thus $\mathrm{Pd}_{2} \mathrm{Ni}_{3}-\mathrm{TiO}_{2}$ shows the best catalytic activity toward FAO. At the same time, the strong interactions between $\mathrm{TiO}_{2}$ and metals (strong metal-support interaction, SMSI) have been shown in previous research, ${ }^{37}$ thus the stability of the catalysts will be enhanced. Compared with the oxidation peak potential of formic acid in the literature, ${ }^{38} \mathrm{Pd}_{2} \mathrm{Ni}_{3}-\mathrm{TiO}_{2}$ did not show excellent catalytic activity for FAO with a more positive oxidation peak potential, and the possible reason is the low electronic conductivity of $\mathrm{TiO}_{2}$ though oriented $\mathrm{TiO}_{2}$ NRs, which were hydrothermally grown on carbon fibers. Meanwhile, compared with the similar state-of-the-art Pd-based electrocatalysts, the as-prepared $\mathrm{Pd}_{2} \mathrm{Ni}_{3}-\mathrm{TiO}_{2}$ exhibits higher mass activity than most of them (Table $\mathrm{S} 1 \dagger$ ).

To further evaluate the surface poisoning, CA curves of Pd$\mathrm{TiO}_{2}, \mathrm{Pd}_{2} \mathrm{Ni}_{3}-\mathrm{TiO}_{2}$, and commercial PdC were investigated in $0.5 \mathrm{M} \mathrm{H}_{2} \mathrm{SO}_{4}+0.5 \mathrm{M} \mathrm{HCOOH}$ with the potential of $0.25 \mathrm{~V}$ for $4000 \mathrm{~s}$ during the measurements (Fig. 4d). It is obvious that the decrease in current density for the FAO on the $\mathrm{Pd}_{2} \mathrm{Ni}_{3}-\mathrm{TiO}_{2} \mathrm{NRs}$ is slower than that of the $\mathrm{Pd}-\mathrm{TiO}_{2} \mathrm{NRs}$ and commercial PdC, which indicates its higher tolerance to the intermediaries during FAO. The improvement of the catalytic performance is possibly attributed to the alloying effect and the advanced catalytic structure.

\section{Conclusions}

In conclusion, we have designed and synthesized a threedimensional catalytic structure based on $\mathrm{TiO}_{2}$ NRs. We found that $\mathrm{Pd}_{2} \mathrm{Ni}_{3}-\mathrm{TiO}_{2}$ catalysts show higher mass activity and higher durability than $\mathrm{Pd}-\mathrm{TiO}_{2}$ catalysts and commercial PdC catalysts. Moreover, the improved catalytic activity of the $\mathrm{Pd}_{2} \mathrm{Ni}_{3}-\mathrm{TiO}_{2}$ catalyst is taking advantage of its unique three-dimensional structure and the alloying effect during FAO. In addition, this work provides a new avenue to design electrocatalysts with superior catalytic activity and stability for DFAFCs and they can be used as an electrode directly.

\section{Acknowledgements}

We are thankful to the National Basic Research Program of China (973 program no. 2015CB932304), and the National Natural Science Foundations of China (no. 91434106, 21473197, 91434131, 61433013 and 21406218) for financial support. 


\section{Notes and references}

1 X. Yu and P. G. Pickup, J. Power Sources, 2008, 182, 124-132.

2 V. Mazumder and S. Sun, J. Am. Chem. Soc., 2009, 131, 45884589.

3 E. Antolini, Energy Environ. Sci., 2009, 2, 915-931.

4 J. Tiwari, R. Tiwari, G. Singh and K. S. Kim, Nano Energy, 2013, 2, 553-578.

5 L. Ying Zhang, Z. L. Zhao and C. M. Li, Nano Energy, 2015, 11, 71-77.

6 M. Rezaei, S. H. Tabaian and D. F. Haghshenas, J. Mater. Chem. A, 2014, 2, 4588-4597.

7 P. Kannan, T. Maiyalagan and M. Opallo, Nano Energy, 2013, 2, 677-687.

8 J. Wang, Y. Chen, H. Liu, R. Li and X. Sun, Electrochem. Commun., 2010, 12, 219-222.

9 T. C. An, W. B. Zhang, X. H. Zhu, Y. Xiong, G. Y. Sheng and J. M. Fu, Chin. J. Catal., 2003, 24, 338-342.

10 C. Du, M. Chen, W. Wang and G. Yin, ACS Appl. Mater. Interfaces, 2011, 3, 105-109.

11 K. C. Poon, B. Khezri, Y. Li, R. D. Webster, H. Su and H. Sato, Chem. Commun., 2016, 52, 3556-3559.

12 Y. Lu and W. Chen, J. Phys. Chem. C, 2010, 114, 21190-21200.

13 R. Li, Z. Wei, T. Huang and A. Yu, Electrochim. Acta, 2011, 56, 6860-6865.

14 V. Mazumder, M. Chi, M. N. Mankin, Y. Liu, O. Metin, D. Sun, K. L. More and S. Sun, Nano Lett., 2012, 12, 11021106.

15 L. Chen, H. Guo, T. Fujita, A. Hirata, W. Zhang, A. Inoue and M. Chen, Adv. Funct. Mater., 2011, 21, 4364-4370.

16 Y. She, Z. Lu, W. Fan, S. Jewell and M. K. H. Leung, J. Mater. Chem. A, 2014, 2, 3894-3898.

17 Y. Zhou, X.-C. Hu, Q. Fan and H.-R. Wen, J. Mater. Chem. A, 2016, 4, 4587-4591.

18 W. Xu, S. Zhu, Z. Li, Z. Cui and X. Yang, Electrochim. Acta, 2013, 114, 35-41.

19 H. An, H. Cui, D. Zhou, D. Tao, B. Li, J. Zhai and Q. Li, Electrochim. Acta, 2013, 92, 176-182.
20 N. Mojumder, S. Sarker, S. A. Abbas, Z. Tian and V. Subramanian, ACS Appl. Mater. Interfaces, 2014, 6, 55855594.

21 Q. Lv, K. Li, C. Liu, J. Ge and W. Xing, Carbon, 2016, 98, 126137.

22 S. F. Jiang, B. L. Yi, C. K. Zhang, S. Liu, H. M. Yu and Z. G. Shao, J. Power Sources, 2015, 276, 80-88.

23 S. F. Jiang, B. L. Yi, H. J. Zhang, W. Song, Y. Z. Bai, H. M. Yu and Z. G. Shao, ChemElectroChem, 2016, 3, 734-740.

24 S. F. Jiang, B. L. Yi, Q. Zhao, H. J. Zhang, Y. Su, H. M. Yu and Z. G. Shao, RSC Adv., 2016, 6, 82370-82375.

25 D. Bin, B. Yang, F. Ren, K. Zhang, P. Yang and Y. Du, J. Mater. Chem. A, 2015, 3, 14001-14006.

26 R. Zhao, Y. Liu, C. Liu, G. Xu, Y. Chen, Y. Tang and T. Lu, J. Mater. Chem. A, 2014, 2, 20855-20860.

27 J. Chang, L. Feng, C. Liu, W. Xing and X. Hu, Angew. Chem., Int. Ed., 2014, 53, 122-126.

28 C. X. Guo, L. Y. Zhang, J. Miao, J. Zhang and C. M. Li, Adv. Energy Mater., 2013, 3, 167-171.

29 H. Zhao, J. Yang, L. Wang, C. Tian, B. Jiang and H. Fu, Chem. Commun., 2011, 47, 2014-2016.

30 W. Wang, S. Ji, H. Wang and R. Wang, Fuel Cells, 2016, 6, 1129-1133.

31 M. Wang, W. Zhang, J. Wang, A. Minett, V. Lo, H. Liu and J. Chen, J. Mater. Chem. A, 2013, 1, 2391-2394.

32 S. Hu, F. Munoz, J. Noborikawa, J. Haan, L. Scudiero and S. Ha, Appl. Catal., B, 2016, 180, 758-765.

$33 \mathrm{~S}$. Hu, L. Scudiero and S. Ha, Electrochem. Commun., 2014, 38, 107-109.

34 A. Ruban, B. Hammer, P. Stoltze, H. L. Skriver and J. K. Nørskov, J. Mol. Catal. A: Chem., 1997, 115, 421-429.

35 Y. Wang, Y. Qi, D. Zhang and C. Liu, J. Phys. Chem. C, 2014, 118, 2067-2076.

36 K. Jiang, H.-X. Zhang, S. Zou and W.-B. Cai, Phys. Chem. Chem. Phys., 2014, 16, 20360-20376.

37 C. Zhang, H. Yu, Y. Li, Y. Gao, Y. Zhao, W. Song, Z. Shao and B. Yi, ChemSusChem, 2013, 6, 659-666.

38 H. Wan, Q. Dong, G. Zhu, G. Yu, T. Yin and M. Huang, Int. J. Hydrogen Energy, 2015, 40, 14179-14186. 